\title{
Central African Economic and Monetary Community: Financial System Stability Assessment, including Reports on the Observance of Standards and Codes on the following topics: Monetary and Financial Policy Transparency, and Banking Supervision
}

This Financial System Stability Assessment on the Central African Economic and Monetary Community (CEMAC) was prepared by a staff team of the International Monetary Fund and the World Bank as background documentation for the periodic consultation with the CEMAC. It is based on the information available at the time it was completed on June 14, 2006. The views expressed in this document are those of the staff team and do not necessarily reflect views of the member countries of the CEMAC or the Executive Board of the IMF.

The policy of publication of staff reports and other documents by the IMF allows for the deletion of market-sensitive information.

To assist the IMF in evaluating the publication policy, reader comments are invited and may be sent by e-mail to publicationpolicy@imf.org.

Copies of this report are available to the public from

International Monetary Fund $\bullet$ Publication Services

700 19th Street, N.W. • Washington, D.C. 20431

Telephone: (202) 6237430 • Telefax: (202) 6237201

E-mail: publications@imf.org • Internet: http://www.imf.org

Price: $\$ 15.00$ a copy

\section{International Monetary Fund Washington, D.C.}





\title{
INTERNATIONAL MONETARY FUND
}

\section{CENTRAL AFRICAN ECONOMIC AND MONETARY COMMUNITY}

\section{Financial System Stability Assessment}

\author{
Prepared by the Monetary and Financial Systems and African Departments \\ Approved by Ulrich Baumgartner and Abdoulaye Bio Tchané
}

June 14, 2006

The Financial System Stability Assessment is based on the work of joint IMF-World Bank FSAP missions that visited the Central African Economic and Monetary Community (CEMAC) in January and March 2006. The team comprised Bernard J. Laurens (co-leader, MFD) and Ann Rennie (co-leader, World Bank); Christian Mulder, Jérome Vacher, and Samer Saab (all MFD), Jakob Christensen (AFR), Emmanuelle Olléon-Assouan (Banque de France), Wafa Sfar (Banque Centrale de Tunisie); Pauline Aranda, Fatou Assah, Jennifer Isern, Jonathan Darboux, Henri Fortin, Andres Jaime, Olivier Hassler, Cédric Mousset, and Don Mc Isaac (all World Bank). The assessment of the AML-CFT regime was carried out by a World Bank team led by Jean Pesme.

- Financial intermediation among the lowest in Africa, is hampered by limits on deposit and lending rates that are out of line with market fundamentals; severe deficiencies in the legal and judicial framework; the poor quality of financial data; and weak payment systems.

- The efficiency of supervision suffers from limited institutional independence of the Central African Banking Commission (COBAC); some divergence of prudential norms from international standards; poor enforcement of regulations; and inadequate resources allocated to the COBAC.

- The banks are vulnerable to a concentration of lending to a few sectors and clients.

- Inadequate cash management practices by governments and weaknesses in the monetary policy framework limit the ability of the Bank of Central African States (BEAC) to manage liquidity and exacerbate financial sector vulnerabilities.

- The scope for regional integration of the financial sector is limited due to low intraregional trade and deficiencies in market infrastructure.

- The mission discussed its findings and recommendations with the regional authorities, which in turn will discuss them with the national authorities at a meeting of the Ministerial Committee planned for early July. The implementation of the mission's recommendations will require technical assistance, and follow up by IMF country teams at the regional and national levels.

FSSAs are designed to assess the stability and performance of the financial system as a whole and not that of individual institutions. FSSAs do not cover risks that are specific to individual institutions such as asset quality, operational or legal risks, or fraud.

This report was prepared by Bernard J. Laurens, Christian Mulder, Jérome Vacher, Samer Saab (all MFD), and Jakob Christensen (AFR). 
I. Overall Assessment of Stability, Integration and Development Issues.............................4

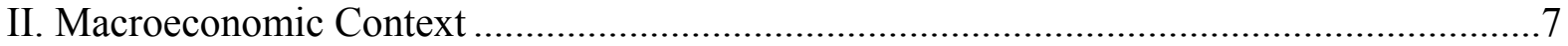

A. Macroeconomic Risks Affecting the Financial Sector ......................................... 7

B. Systemic Liquidity Management ....................................................................

III. Structure, Performance, and Stability of the Financial Sector......................................13

A. Structure and Performance of the Financial Sector ...........................................13

B. Soundness and Short-Term Vulnerabilities in the Banking Sector........................14

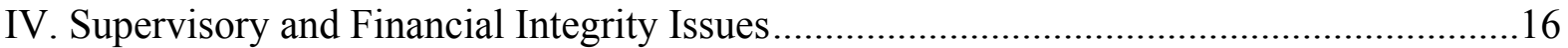

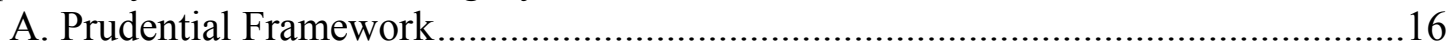

B. Deposit Insurance and Lender of Last Resort ................................................... 18

C. Anti-Money Laundering and Combating the Financing of Terrorism ...................19

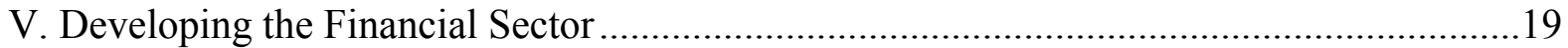

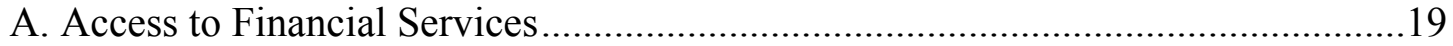

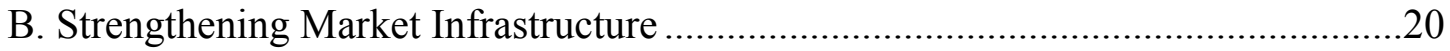

C. Development Bank and Financial Market.......................................................22

Tables

1. Structure of the Financial System, December 2005 ...........................................13

2. Selected Financial Soundness Indicators and Banks' Ratings, 2002-05...................15

3. Recommended Action Plan to Improve Compliance of the Basel Core Principles.....28

Figures

1. Systemic Liquidity Management Indicators ....................................................... 10

\section{Boxes}

1. Governments' Cash Management and BEAC's Corporate Governance .....................11

2. Remuneration of Government Deposits by BEAC .............................................12

Appendix

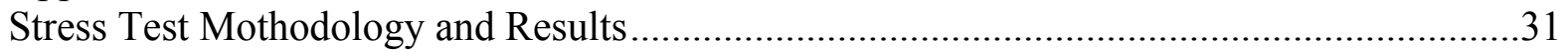

Statistical Tables

1. Selected Economic and Financial Indicators, 2000-05 ............................................33

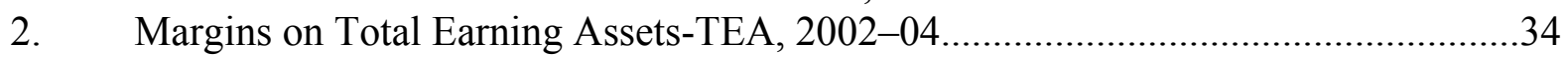

3. Selected Financial Soundness Indicators, 2002-05 ….............................................34

4. Changes in Banks' Ratings, 2001-05 ….............................................................34

Annex

Observance of Financial Sector Standards and Codes-Summary Assessments 


\section{Glossary}

$\begin{array}{ll}\text { AML } & \text { Anti-Money Laundering } \\ \text { BDEAC } & \text { Central African States Development Bank } \\ \text { BEAC } & \text { Bank of Central African States } \\ \text { BVMAC } & \text { Central African Stock Exchange } \\ \text { BRVM } & \text { Regional Stock Exchange } \\ \text { CAR } & \text { Central African Republic } \\ \text { CEMAC } & \text { Central African Economic and Monetary Community } \\ \text { CFT } & \text { Combating the Financing of Terrorism } \\ \text { CI } & \text { Credit Institution } \\ \text { CIMA } & \text { Inter-African Conference on Insurance Markets } \\ \text { COBAC } & \text { Central African Banking Commission } \\ \text { COSUMAF } & \text { Commission on Monitoring of the Financial Market of Central Africa } \\ \text { DSX } & \text { Douala Stock Exchange } \\ \text { ECB } & \text { European Central Bank } \\ \text { FATF } & \text { Financial Action Task Force } \\ \text { FOGADAC } & \text { Central African Deposit Insurance Fund } \\ \text { FSAP } & \text { Financial Sector Assessment Program } \\ \text { FSSA } & \text { Financial System Stability Assessment } \\ \text { GDP } & \text { Gross Domestic Product } \\ \text { ISA } & \text { International Auditing Standards } \\ \text { IFRS } & \text { International Financial Reporting Standards } \\ \text { MFIs } & \text { Microfinance Institutions } \\ \text { OHADA } & \text { Organization for the Harmonization of African Business Law } \\ \text { ROSC } & \text { Report on the Observance of Standards and Codes } \\ \text { SMEs } & \text { Small and Medium-Sized Enterprises } \\ \text { SOEs } & \text { State-Owned Enterprises } \\ \text { TSA } & \text { Treasury Single Account } \\ \text { WAEMU } & \text { West African Economic and Monetary Union } \\ & \end{array}$




\section{OVERALl ASSESSMENT OF StABILITy, INTEGRATION AND DEVELOPMENT ISSUES}

1. The financial sector of the Central African Economic and Monetary Community (CEMAC) lacks depth, is highly fragmented, and its stability is exposed to significant risks. Access to financial services is among the lowest in Africa; and the sector is dominated by a noncompetitive banking sector which is highly vulnerable to credit risk. The lack of institutional independence of the Central African Banking Commission (COBAC) has resulted in poor enforcement capacity, at times leading to protracted noncompliance with critical prudential norms by several banks. Weaknesses in cash management practices by governments and in the systemic liquidity management framework exacerbate financial sector vulnerabilities.

\section{Short-term risks to the banking sector and prudential framework}

2. The banking sector is vulnerable to credit risk. A large number of banks are undercapitalized given their risk exposure to few sectors and borrowers and the weak judicial framework for enforcing creditor rights. In view of those risks, the mission recommended raising the minimum capital adequacy ratio above the current 8 percent.

3. Financial supervisors, particularly in the banking sector, are well trained, but the interference of the national authorities in some aspects of financial supervision, together with an acute shortage of staff, limits the overall effectiveness of the supervisory framework. The mission emphasized that full enforcement of prudential norms and stronger use of corrective actions would require further curtailing the role of the national authorities in the issuance or withdrawal of bank licenses. The regional authorities indicated that they would increase staffing of the supervisory agencies, and that FSAP recommendations will be used to prepare an action plan to ensure full consistency of the prudential framework with international standards.

4. Significant steps were taken by COBAC and the banking sector to implement the regional framework for AML-CFT, but the division of labor between and accountability of the regional and national authorities needs to be clarified. In particular, the national authorities should confirm their commitment to AML-CFT by promptly establishing the national Financial Intelligence Units and building up their operational capacities.

\section{Systemic liquidity}

5. The Bank of Central African States (BEAC) conducts monetary policy in the context of a fixed exchange rate against the Euro. While the BEAC formulates common monetary policy targets, systemic liquidity management remains largely country-based due to the lack of integration of the money market. The financial relations between the BEAC and CEMAC governments do not ensure a clear separation between money creation and budget financing (all the CEMAC countries but one have had recourse to advances from the $\mathrm{BEAC}$ ), and the growing fiscal surpluses in several countries have brought to the forefront the issue of BEAC remuneration of government deposits. 
6. Inadequate cash management practices by governments and the lack of an efficient monetary policy implementation framework limit the ability of the BEAC to tackle effectively the current excess liquidity:

- Continued recourse to monetary financing ("avances statutaires") by governments and the placement of government deposits with local banks have contributed to the excess liquidity and complicated liquidity management by the BEAC. It cannot be ruled out that the abundance of liquidity may have led to risky lending.

- A negative spread has arisen between interest rates in the CEMAC and those in the euro area; the monetary program is not used to assess the volume of liquidity to be absorbed; liquidity absorption has declined; and limited transparency in monetary policy implementation and the recourse to administrative measures have hampered money market development.

7. In order to encourage the centralization of government balances at the central bank the authorities have recently adopted a new framework for the remuneration of government deposits with the BEAC. The authorities need to ensure that the remuneration on the deposits remains adequate, while not jeopardizing the profitability of the BEAC. A review of the BEAC's accounting rules is desirable in this regard to ensure consistency with best international practices, and allow a well informed decision on the level of remuneration provided on government deposits.

8. Greater reliance on market-based instruments for monetary policy conduct and public debt management is desirable. The BEAC should introduce central bank bills to conduct liquidity management operations, strengthen its corporate governance and the transparency in monetary policy implementation, and raise the rate at which it conducts its liquidity absorbing operations at least to the level of the European Central Bank's policy rate. CEMAC governments should introduce treasury bills markets so that monetary financing by the $\mathrm{BEAC}$ can be eliminated. Implementation of the regional monetary program would also benefit from developing a framework to assess the level of international reserves sufficient to absorb oil related shocks, and the resulting level of savings by the oil-producing states. Immediate action in these areas is warranted, as the weaknesses identified may exacerbate financial sector vulnerabilities.

\section{Financial sector integration and development}

9. So far, the common currency and a comprehensive and well-structured regional institutional setup have not led to financial integration in the region. Significant strides have been achieved to regulate the financial sector at the regional level, but limited progress has been made in facilitating the integration of markets. Foremost, low intraregional trade limits the scope for financial integration. Other obstacles to integration include deficiencies in infrastructure and markets; and the limited effectiveness of the "agrément unique" framework that aims at facilitating cross-border activities of banks established within the CEMAC. The mission emphasized the need to design a coherent strategy to develop regional 
interbank and debt markets consistent with efforts aimed at improving the systemic liquidity framework, and review the appropriateness of the "agrément unique" framework.

10. Deepening financial intermediation, which is among the lowest in the world, calls for a more competitive environment and addressing administrative constraints. The mission found that severe deficiencies in the business environment are discouraging banks to develop their financial services to SMEs as well as ties with the microfinance sector. These include flaws in the legal and judicial framework, the poor quality of financial data and weak payment systems. In addition, the imposition of minimum deposit and maximum lending interest rates which are not in line with market fundamentals has induced banks to impose high minimum savings balances and management fees. The mission stressed the need to focus on solving these deep-seated problems rather than creating specialized and government-sponsored financial institutions to increase financial intermediation.

11. The regional OHADA legal framework has led to a number of improvements, but credit activities remain hampered by significant deficiencies at the implementation stage of the framework. Debt collection and foreclosure on collateral remain inefficient because of complex procedures established by OHADA, uncertainties in each country's civil procedure, and weak capacity and problems of governance in the judicial systems. The OHADA framework could be enhanced in the areas of secured transactions and collateral as well as enforcement and insolvency procedures.

12. Two parallel yet independent stock markets are being developed in the CEMAC, despite potential legal and financial incompatibilities. Given the relatively high fixed costs associated with the operation of a stock market and the narrow base of potential issuers and investors, the two markets should be merged.

\section{The way forward}

\section{A wide-ranging reform agenda is necessary for CEMAC to meet current} challenges. The mission's recommendations that have the most marked impact on the stability and development and integration of the financial sector would consist of the following:

- Financial sector supervision: reduce further the powers of the national authorities in the issuance or withdrawal of bank licenses ${ }^{\mathrm{N}}(\mathrm{ST})$, increase staffing levels at the COBAC ${ }^{\mathrm{R}-\mathrm{N}}$ (ST), enforce fully current regulations, including for AML-CFT ${ }^{\mathrm{R}-\mathrm{N}}(\mathrm{ST})$, and strengthen further the consistency of the prudential framework with international standards ${ }^{\mathrm{R}}(\mathrm{MT}){ }^{1}$

- Systemic liquidity management and recycling of fiscal surpluses: centralize government cash balances at the $\mathrm{BEAC}^{\mathrm{N}}(\mathrm{ST})$, reinforce the use of market-based instruments for

${ }^{1 \mathrm{R}}$ : action to be taken at the regional level; ${ }^{\mathrm{N}}$ : action to be taken at the national level; ST: short term (i.e., within a year or two); MT: medium term (up to three-four years). 
monetary $^{\mathrm{R}}$ and public debt management ${ }^{\mathrm{N}}(\mathrm{MT})$, and establish a framework to assess a desirable target for international reserves ${ }^{\mathrm{R}}(\mathrm{ST})$.

- Banking sector stability: increase the minimum capital adequacy ratio for the banks so that they can better absorb shocks ${ }^{\mathrm{R}}(\mathrm{MT})$.

- Access to financial services: foster financial intermediation by bringing the limits on deposit and lending interest rates in line with market fundamentals ${ }^{\mathrm{R}}$ (ST) and ultimately lifting all interest rate controls ${ }^{\mathrm{R}}(\mathrm{MT})$, and strengthen the business environment by enhancing the proper functioning of the legal and judicial framework and strengthening financial infrastructure ${ }^{\mathrm{R}-\mathrm{N}}(\mathrm{MT})$.

14. The regional authorities indicated that plans are being made to strengthen the prudential and systemic liquidity frameworks. They also stressed that technical assistance will be needed, and that several of the mission's recommendations will have to be discussed with the national authorities. In that regard, the mission emphasized that implementation of the reform agenda will require strong ownership on the part of the national authorities, given that some initiatives taken in the past (i.e., phasing out monetary financing and setting up treasury bill markets, regional stock market) have had no effective follow-up. The meeting of the Ministerial Committee that is scheduled to discuss the findings and conclusions of the FSAP could help build consensus for a reform agenda, outline the actions that need to be taken at the national level, and agree on a process to ensure that the regional actions will be complemented at the national level.

\section{MaCroeconomic CONTEXT}

\section{A. Macroeconomic Risks Affecting the Financial Sector}

\section{Macroeconomic performance in the CEMAC region strengthened in $\mathbf{2 0 0 5}$} largely due to higher oil revenue and some fiscal savings of the oil windfall. Fiscal surpluses increased, the external current account turned positive international reserve coverage rose and the external debt burden declined. Growth, however, decelerated, while inflation increased in part due to weather related conditions. As a result of a surge in oil related inflows, regional broad money and credit growth accelerated. However, in the absence of an active sterilization policy by BEAC, excess bank liquidity increased further.

16. The main macro-risks for CEMACs banking sector are the high dependence on oil, narrow economic and corporate lending base, and excess liquidity. The oil sector dominates macroeconomic developments. The region's economy is vulnerable to external shocks because of its high dependence on oil for budgetary revenues and foreign exchange earnings. Five of the six CEMAC countries are oil producers and the sector accounts for 40 percent of the region's output, generates more than 80 percent of export earnings and 50 percent of tax revenues (see Appendix Table 1). Under the fixed exchange rate regime, surges in volatile oil related inflows complicate the conduct of monetary policy, with the effectiveness of monetary policy also undermined by the lack of developed financial markets. 
Banks have in the past been vulnerable to oil price shocks mainly indirectly through a weakening in public finances, in particular during periods of lower oil prices. This, along with no build-up of fiscal savings from previous oil windfalls and shortcomings in cash management, resulted in public debt defaults and arrears accumulation, the latter hampering the ability of government suppliers and employees to service bank loans.

17. The narrow economic and corporate base is another source of risk for the banks. The primary sector accounts for more than 50 percent of economic activity, and the industrial sector plays a limited role compared to other African countries. As such, income volatility is high. Banks exposure to credit risk is further exacerbated by the small number of borrowers.

\section{Finally, excess bank liquidity can result in unsound lending practices and} financial disintermediation. While excess liquidity is primarily related to the surge in oil related inflows and government deposits, it also reflects the lack of bankable projects in the region, restrictions on outward investment, underdeveloped regional financial markets and weaknesses in liquidity management by BEAC. ${ }^{2}$ Liquidity is also not evenly distributed, with established banks holding more than weaker and smaller ones. The prevalence of weak banks in the region and the lack of financial instruments undermine the potential function of the regional interbank market as a venue for recycling excess liquidity. Excess bank liquidity in the past has led to unsound lending practices, as banks have circumvented prudential norms on exposure limits and related party lending, and has been costly to financial intermediation as banks are required to pay a high minimum rate on saving accounts.

\section{B. Systemic Liquidity Management}

19. The BEAC formulates and implements the common monetary policy in the context of a fixed exchange rate against the euro, free capital movement between countries in the CEMAC, but remaining capital controls with non-CEMAC countries. ${ }^{3}$ As its operational framework, the BEAC formulates common monetary policy targets with the view to meeting the foreign exchange cover ratio established in the monetary cooperation agreement with France. ${ }^{4}$ However, liquidity management remains largely country-based due to the lack of integration of the money market. This has allowed the BEAC to apply differentiated reserves requirement ratios to CEMAC countries based on the liquidity situation of their respective banking sectors. Open market type operations in the form of deposits auctions are also used to absorb part of the excess liquidity.

\footnotetext{
${ }^{2}$ Deposits in banks have increased by nearly 25 percent in 2005 due to increased government deposits and the clearance of government arrears following oil related windfalls.

${ }^{3}$ Companies are subject to a repatriation requirement on export proceeds.

${ }^{4}$ The minimum statutory foreign exchange cover ratio (ratio of the BEAC international reserves to its sight liabilities) is 20 percent. At end-2005, it stood at 85 percent.
} 
20. The financial relations between the BEAC and CEMAC governments do not ensure a clear separation between money creation and budget financing. The policy objective formulated at the end of 1999 to phase out monetary financing ("avances statutaires") to governments and to develop treasury bill markets has stalled due to lack of political will, and all the CEMAC countries except one had recourse to the "avances statutaires" as of end 2005. On the other hand, the growing fiscal surpluses in several countries have brought to the forefront the conditions at which the BEAC remunerates government deposits. This has prompted a review of the arrangements in place with a view to increase the attractiveness of the deposits at the BEAC.

21. Monetary policy procedures and cash management practices by CEMAC governments are not well suited to the prevailing excess liquidity in the banking sector:

- While the regional monetary program allows a coordination of monetary and fiscal policy, currently it is not used by the BEAC to assess the volume of liquidity to be absorbed, and there is no framework to assess the adequacy of international reserves to deal with oil sector shocks and determine a corresponding level of government savings (i.e., Funds for Future Generations). ${ }^{5}$

- The absorption of liquidity has declined. In particular, reduced mopping up operations were not fully compensated by an increase in required reserves (Figure 1). ${ }^{6}$

- Limited transparency in monetary policy implementation and the recourse to administrative measures hamper money market development. The governor of the BEAC decides on the use of instruments, at times without reference to clear rules, and transfers abroad have occasionally been subject to prior authorizations which are not contemplated in the exchange regulations (Box 1).

- The current situation of excess liquidity has made evident the inconsistency of CEMAC interest rates with those in the euro area. The BEAC's deposit auction rate, which is the relevant policy rate given the current structural excess liquidity, is below the policy rate of the European Central Bank (ECB) (Figure 1). Therefore, residents have an incentive to export capital, as evidenced by the large foreign exchange positions of the banks. There is also anecdotal evidence of widespread evasion of the requirement for the repatriation of export proceeds.

\footnotetext{
${ }^{5}$ The regional monetary program exercise undertaken by the BEAC is based on the implicit objective of price stability. Economic forecasts and the countries' public finances are analyzed, with a view to calibrate the BEAC's volume of banks' refinancing. Central bank credit to the government ("avances statutaires") is subject to a limit of 20 percent of fiscal revenue in the previous year.

${ }^{6}$ Between December 2003 and October 2005, banks' excess reserves increased by more than CFAF 400 billion. In the meantime, mopping up operations through the BEAC's deposit auctions were cut by CFAF 70 billion (to CFAF 14 billion), and banks' reserves sterilized through required reserves increased by only CFAF 50 billion.
} 
- The poor centralization of government balances at the BEAC (Box 1) has complicated liquidity management by the BEAC. Placement of deposits with local banks has contributed to the excess liquidity, as did the continued recourse of governments to the "avances statutaires" from the BEAC.

Figure 1. Systemic Liquidity Management Indicators
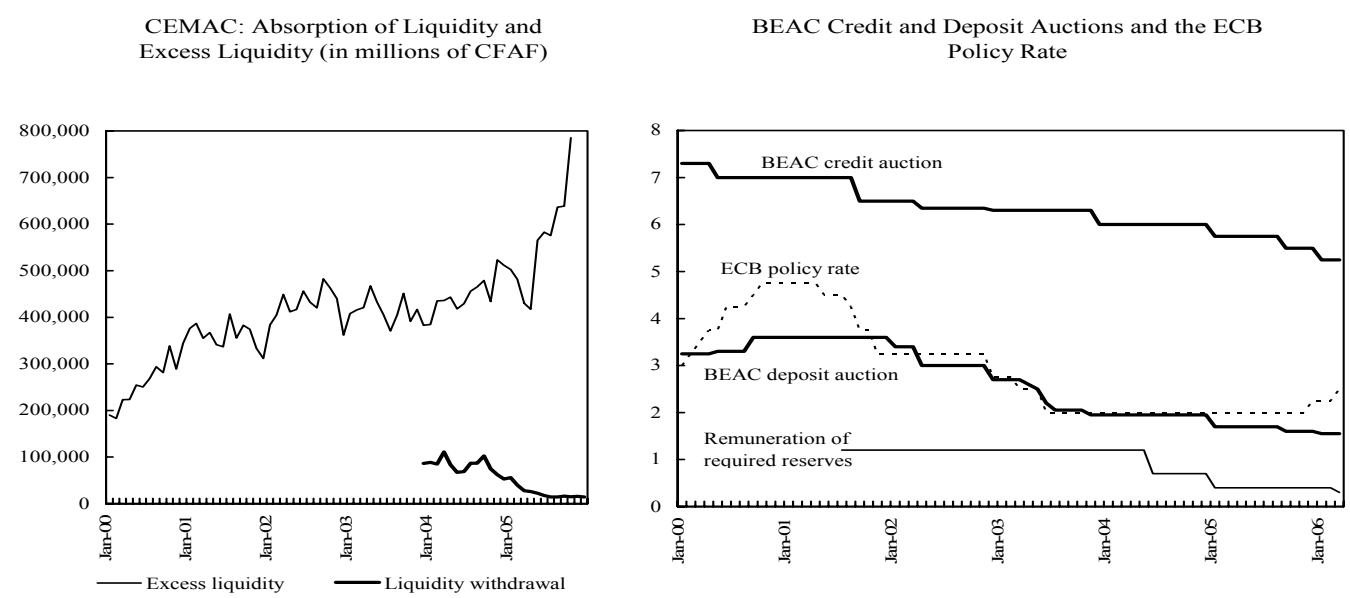

22. The aforementioned problems are also linked to the BEAC's limited use of its market-based liquidity absorption mechanisms. This is due to the preeminence that it gives to cost considerations in the conduct of monetary policy and, to some degree, because of the shallowness of the money market. Cost considerations are also prominent in the BEAC's relations with governments: when deposits at the BEAC are remunerated, they earn only a fraction of the interest earned by BEAC on its deposits with the French treasury. The spread has encouraged the nonrepatriation of oil revenues by the States or the placement of government deposits with local banks. Given the importance of central bank profitability, the authorities should review the consistency of the BEAC's accounting framework with best practices and, thereafter, review the appropriateness of the current mechanism for sharing profits with the CEMAC States.

\section{The lack of an effective framework for liquidity management can potentially} exacerbate banking sector vulnerabilities, and is an obstacle to financial sector development. The BEAC has been able to achieve its intermediate objectives. ${ }^{7}$ However, should the need arise, it is uncertain that the BEAC would be able to tighten monetary policy in view of its reluctance to assume the related costs, and of the lack of effective operational procedures. In addition, the development of financial markets is hampered by reliance on administrative measures in monetary policy conduct and by the excess liquidity.

\footnotetext{
${ }^{7}$ The exchange cover ratio, at about 80 percent, is well above the 20 percent minimum, and inflation seems to be under control. However, the cover ratio is not a good measure of reserves adequacy; the reliability of price indices is limited; and country differences in inflation can be related to their liquidity situation.
} 


\section{Box 1. Governments' Cash Management and BEAC's Corporate Governance}

\section{Governments' cash management}

Cash management by governments is complicated by the number of their accounts in commercial banks. Several

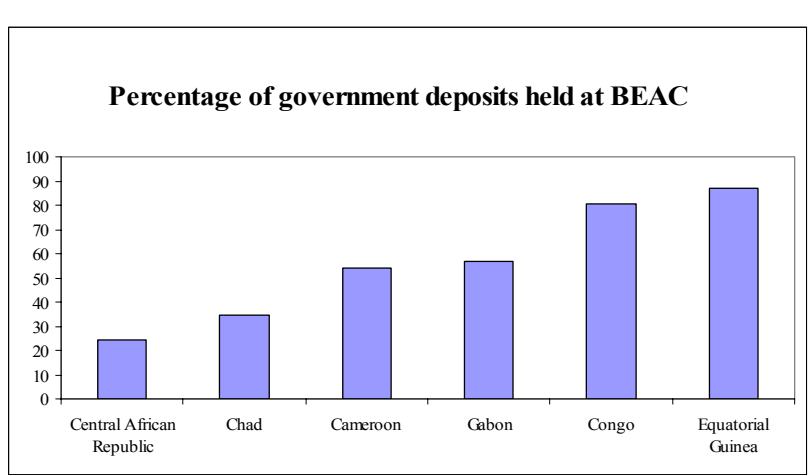
countries hold significant deposits in banks. Given the volatility of these deposits, banks face considerable uncertainty. In addition, the high volume of government deposits outside the central bank complicates liquidity management and the implementation of monetary policy.

To increase transparency and control over government budget execution, some countries are moving to a Treasury Single Account (TSA). Equatorial Guinea has adopted the principle of a TSA, and a TSA has been operating in Cameroon since late 2005. The Central African Republic (CAR) plans to keep one TSA per commercial bank and at the BEAC. Chad has already identified the accounts to be closed and should create a TSA under the petroleum management law (LGP). The Republic of Congo has no plans to adopt a TSA. Gabon has adopted the TSA principle but the law authorizes the government to open bank accounts.

In some countries, there would continue to be one TSA in the banks and another at the BEAC. In Cameroon, government accounts in banks were closed and their balances transferred to the treasury account at the BEAC, except for the accounts of autonomous agencies and those funded by donors. In the CAR, the banks have pressured the government to maintain accounts with them as a guarantee on their advances to the government.

Placements of deposits with local banks does not systematically involve prior assessment of counterparty risks and the mission noted instances of deposits in banks breaching prudential norms (i.e., limits to large exposures, loans to related/connected parties) or with weak internal controls. It cannot be ruled out that the abundance of liquidity in those banks may have led to unwise lending.

\section{BEAC's corporate governance}

The governance framework of the BEAC rests on the Board of Directors (CA) and the governor. The CA is made up of 13 members appointed by CEMAC countries and France. Article 46 of the Statutes highlights the conflict of interest rules applicable to members of the $\mathrm{CA}$ and the governor, and the independence of the governor, vice-governor, and general secretary.

The role of the governor is more important than the Statutes might suggest and the direct exercise of its responsibilities encourages discretion in decision making. The CA has delegated some of its powers to the governor. Hence, he has responsibility for the definition of monetary policy and its implementation. The governor exercises these powers directly. A monetary policy council (consisting of the governor and BEAC staff) was set up but it has not met for the last two years. Monetary policy decisions are not taken according to a schedule known in advance; the considerations that dictate them are not well known to the market; and the eligibility of banks to monetary operations as well as the allocation of deposits at the periodic deposit auctions does not conform to transparent rules.

More collegiality in policymaking and clear rules for the use of instruments would strengthen the BEAC's credibility:

- A monetary policy board (CPM) should be established with responsibility for monetary policy formulation and decisions. Its independent members would be appointed by the governments, while the BEAC governor and vice-governor would be members, with the governor as chairperson.

- A monetary policy implementation committee should be created by the CPM and chaired by the governor. It would be responsible for the transparent implementation of the decisions of the CPM, based on clear rules regarding eligibility for monetary policy operations and their use. Clear rules would allow monetary policy decisions and authorizations in the area of exchange regulations to be implemented through a decentralized procedure itself subject to a level of administrative recourse. 


\section{Improving monetary policy requires increased transparency, centralization of government balances at the $\mathrm{BEAC}$, and enhanced reliance on market forces:}

- The transparency of monetary policy would benefit from the creation of committees at the BEAC and clear rules for the use of the monetary instruments (Box 1).

- Reforms to improve centralization of government cash balances (Box 1) should be completed, and the Treasury Single Account should be located at the BEAC.

- The BEAC needs to assess the volume of liquidity to be withdrawn from the system and to conduct its mopping up operations at interest rates better reflecting market conditions. To that effect, the BEAC's deposit auction rate should be raised at least to the level of the ECB policy rate (i.e., from 1.55 to at least 2.5 percent).

- $\quad$ The principles adopted in April 2006 for the remuneration of government deposits at the BEAC appropriately recognize the need to safeguard its profitability (Box 2). It will also be important to ensure that the remuneration provides an incentive to the repatriation at the BEAC of all government revenues, and it is not clear that the remuneration being offered by the BEAC, in particular on the Funds for Future Generations, meets this condition. ${ }^{8}$ Furthermore, an alternative to investing the Funds for Future Generations with the BEAC may be considered. These Funds have a long-term horizon, their assets should not be available for balance of payments purposes, and they require

\section{Box 2. Remuneration of Government Deposits by} BEAC

The April 2006 mechanism for the remuneration of government deposits is based on the indexation on the interest earned by BEAC on its deposits with the French Treasury (i.e., ECB policy rate plus 100 basis points, that is 3.50 percent currently) minus a margin to ensure the profitability of BEAC.

Conventional deposits (dépôts spéciaux classiques). One-month minimum maturity. Remuneration for countries with outstanding advances from BEAC is 0.50 percent, and 1.40 percent for the other countries. Fiscal Revenue Stabilization Mechanisms. Minimum maturity of six month. Remuneration is 1.70 percent, subject to a 30 percent reduction in case of withdrawals before maturity.

Fund for Future Generations. Minimum maturity of five years. Remuneration rate is currently set at 1.90 percent, subject to a retroactive reduction in case of withdrawals before maturity.

involvement of the countries in the investment strategies. The Funds could be entrusted to external managers, with an oversight function by the BEAC.

\section{The effectiveness of monetary policy would further benefit from a clear} separation between money creation and budget financing. This would require launching treasury bill markets to allow the BEAC to phase out monetary financing ("avances statutaires") to governments. Strengthened cash management practices by governments and

\footnotetext{
${ }^{8}$ The yield to be expected on Funds for Future Generations if invested in risk free assets should match those in 5-10 year government bonds (currently yielding 3.7 to 4 percent). If a proportion is invested in equity, expected returns may be higher.
} 
the centralization of balances at the BEAC would further facilitate this reform. However, given the fiscal surpluses and accumulation of deposits by most governments in the CEMAC and a weak credit reputation in some, large-scale issuance should not be expected. Therefore, to help mop up the sizable excess liquidity and at the same time encourage money market development, the BEAC should introduce tradable central bank bills, and the related financial costs should be taken into account to set the margin left to the BEAC as discussed in Box 2 .

\section{Structure, Performance, And Stability of the Financial Sector}

\section{A. Structure and Performance of the Financial Sector}

26. The financial system is bank-dominated (Table 1). As of end-2005, 31 of the 33 banks are privately owned, and they are highly concentrated in four out of the six countries, with Cameroon and Gabon accounting for three-fourths of total banking assets. Non-bank financial institutions do not play a significant role (6 percent of financial assets), and microfinance institutions (MFIs) control less than 4 percent of deposits. The insurance sector is barely developed: insurance premiums represent less than 1 percent of GDP, but the number of companies has increased from 29 in 2002 to 36 in 2006, encouraged by the low capital requirement. Threequarters of the insurance companies are in Cameroon and Gabon. Pension benefits in the CEMAC area are provided by government managed institutions which hold limited volume of assets. The CEMAC has a regional development bank (BDEAC) expected to play a role in the promotion of regional integration.

Table 1. Structure of the Financial System, December 2005

\begin{tabular}{lcccr}
\hline & Number & $\begin{array}{c}\text { Assets } \\
\text { (CFAF billion) }\end{array}$ & $\begin{array}{c}\text { Percentage } \\
\text { Assets }\end{array}$ & $\begin{array}{c}\text { Percentage } \\
\text { GDP }\end{array}$ \\
\hline Banks & 33 & $3,132.3$ & 86.7 & 15.8 \\
Private & 31 & $3,020.0$ & 83.6 & 15.3 \\
Local & 8 & 869.0 & 24.0 & 4.4 \\
Foreign 1/ & 23 & $2,151.0$ & 59.5 & 10.9 \\
Government & 2 & 112.3 & 3.3 & 0.6 \\
Nonbank financial institutions & 17 & 215.2 & 5.6 & 1.1 \\
Microfinance & 1,018 & 133.0 & 3.6 & 0.5 \\
Insurance companies & 36 & 164.0 & 4.5 & 0.8 \\
Total financial system & $\ldots$ & $3,644.5$ & 100.0 & 18.2 \\
\hline
\end{tabular}

Source: COBAC. 1/ Foreign banks are those controlled by an entity outside the CEMAC.

27. Financial groups play an important role in the banking sector, and the role of the public sector has declined. The presence of financial groups in several countries contributes to the integration of the financial sector. Two foreign banks have each established a presence in three CEMAC countries, and together represent about one-third of the sector. Three other banking groups are present in three or more countries. However, so far the 
"agrément unique" framework has not been used. ${ }^{9}$ The share of bank capital held by governments has declined from an average of 24 percent in 2002 to 20 percent in 2005 . With the exception of the CAR and Chad, direct lending to governments is limited, as are the holdings of government securities, with the exception of banks in Cameroon and Gabon. Two-thirds of the banks, representing 60 percent of banking assets, have majority foreign ownership.

28. The banking sector is shallow, its sources of funding are poorly diversified, and lending opportunities are limited. Banks' total assets amount to only 16 percent of GDP, and lending to the private sector to 7 percent (15 percent for sub-Saharan Africa). The minimum deposit rate, at 4.25 percent, is well above market conditions, and this an obstacle to financial intermediation, particularly in a context of excess liquidity. In effect, volatility of deposits has increased in some countries, and highly concentrated deposits consisting mostly of demand or short-term deposits limit the supply of long-term financing. With the exception of Gabon, where 10 percent of deposits must be placed in government securities, banks have few opportunities to invest in securities, and they serve a small number of corporate clients. In that context, the maximum lending rate (15 percent) constrains the optimal pricing of risk, limits client diversification to SMEs and households, and leads the banks to boost profitability by increasing fees (Statistical Table 2), a practice that limits financial intermediation.

29. The profitability of banks exhibits a declining trend. For 2005, the average return on assets (ROA) is 1.8 percent, and the return on equity (ROE) is close to 17 percent, slightly lower than in 2002 (Table 2). However, there are significant variations between countries, and foreign banks with the highest capital adequacy ratio show ROEs slightly lower than local banks. Gross margins on interest-earning assets are also declining, due to a reduction in average return on loans (11 percent in 2004) while the average cost of funds (2.5 percent) remains stable, although with sharp differences between countries (Statistical Table 2). Gross margins may seem substantial but they reflect risks inherent to bank lending in the CEMAC, particularly credit and operating risks. The increase in fees helped contain the effect on overall profitability of declining margins.

\section{B. Soundness and Short-Term Vulnerabilities in the Banking Sector}

\section{Soundness of the banking sector}

30. Despite continued improvement in economic conditions, the banking system remains vulnerable with pronounced variations among countries. As of end 2005, the average capital adequacy ratio was 14.8 percent (Table 2), although the improvement

\footnotetext{
9 The "agrément unique" framework was instituted in 2000 to allow facilitate cross-border activities of banks established within the CEMAC. No application has been filed due to a limited need for it but also the reluctance of national authorities to allow new banks to compete with existing ones.
} 
recorded that year reflects changes in the calculation of weighted assets. ${ }^{10}$ Eight banks, representing 18 percent of the system's assets, are under the 8 percent minimum, and five of these show negative equity. ${ }^{11}$ Asset quality has not improved much, but COBAC efforts have led to improved provisioning, with an average provisioning rate of 79 percent. While some banking systems are slowly emerging from a precarious situation (CAR), two countries show a weakening in asset quality despite a favorable economic situation (Congo and Equatorial Guinea). Overall, the ratings by COBAC exhibit an increased number of banks favorably rated, but also a sharp increase in the number of negatively rated banks (Table 2).

\section{Short-term vulnerabilities}

Table 2. Selected Financial Soundness Indicators and Banks' Ratings 2002-05 (In percent, unless otherwise indicated)

\begin{tabular}{lll}
\hline & \multicolumn{2}{l}{ CEMAC } \\
\cline { 2 - 3 } & 2002 & 2005 \\
\hline Capital adequacy ratio & & \\
Weighted ratio 1/ & 11.4 & 10.8 \\
Weighted ratio 2/ & $\ldots$ & 14.8 \\
Capital/assets & 10.5 & 10.8 \\
Asset quality, profitability and liquidity & & \\
Gross NPL/gross loans & 13.9 & 13.7 \\
Net NPLs/gross loans & 3.4 & 2.6 \\
Net NPLs/capital & 18.2 & 11.6 \\
Assets return (ROA) & 2.2 & 1.8 \\
Equity return (ROE) & 21.0 & 16.9 \\
Liq. assets/total assets & 16.0 & 22.1 \\
Liq. assets/demand deposits & 29.3 & 38.5 \\
Banks' ratings (in number of banks rated) 3/ & 25 & 33 \\
Solid and Good & 16 & 22 \\
Slightly Fragile and Moderately Fragile & 7 & 5 \\
Very Fragile and Critical & 2 & 6 \\
\hline Sorce: COBAC and
\end{tabular}

Source: COBAC and staff estimates. 1/ Estimates based on weights used prior to 2005. 2/ Estimates based on weights used since 2005. 3/ Ratings are for the years 2001 and 2005. See Appendix Tables 2 and 3 for country results.

\section{The stress tests summarized in the Appendix indicate that credit risk is the main source of vulnerability:}

- A sharp deterioration in the quality of loans would lead to a significant decline in the capital adequacy ratio of banks in Chad, Cameroon, and the CAR. For the CEAMC, twelve banks would not comply with the minimum capital adequacy ratio, and six of them would have negative equity.

- Widespread noncompliance with large exposure limits is a major source of vulnerability. Default by each bank's largest borrower would bring most capital adequacy ratios below 8 percent, with banks in Chad, Equatorial Guinea, and Congo being the most exposed. Only the Gabonese banking system would continue to comply.

- Banks in Gabon, Cameroon, Congo, and Equatorial Guinea are vulnerable to a downturn in the forestry sector. Adverse developments in the oil sector would have an indirect

\footnotetext{
${ }^{10}$ A decline from 100 to 20 percent of the weight applied to correspondent accounts in OECD, CEMAC, and WAEMU; a weight to loans to governments based on convergence criteria instead of the previous 100 percent.

${ }^{11}$ Equity requirements would represent only 0.1 percent of GDP in the CEMAC. The deposits of banks with negative equity represent 0.4 percent of regional GDP ( 0.7 percent in Cameroon and 2.5 percent in the CAR).
} 
effect on the banks in oil producing countries, due to weaker fiscal performances, but the effect would be contained because the banks have limited direct exposure to the sector.

32. Large long foreign currency positions protect banks against a depreciation of the currency. Eleven banks have net positions that exceed twice their regulatory capital, with the positions of Gabonese and Congolese banks being the largest, and those of domestic banks and banking groups being larger than those of foreign banks. ${ }^{12}$ In the event of an appreciation of the currency against the euro (and to a lesser extent against the dollar), the capital adequacy ratio of banks in Cameroon and Congo and of some other domestic banks and local groups would fall short of the regulatory minimum. Gabonese banks would be less affected due to a high capital adequacy ratio, and local groups would suffer more than foreign ones.

33. Banks' exposure to liquidity risks appears limited, with banks in Cameroon being the most vulnerable. A withdrawal of all demand deposits by central governments ${ }^{13}$ and half of their term deposits would also have, overall, a modest effect. However, large deposits by the public sector have boosted the liquidity position of some banks which, therefore, are highly exposed to sudden withdrawals.

\section{The banks are somewhat exposed to interest rate risk despite the lack of long-} term intermediation. As most bank loans are at fixed rates, an increase in short-term rates or in the cost of funds would have a significant impact: a shift upward of the yield curve by 500 basis points would primarily affect banks in Cameroon (a four-point reduction in the capital adequacy ratio) and Gabon. An increase in short-term rates only would have a similar effect on the capital adequacy ratio of the banks.

\section{SUPERVISORY AND FINANCIAL INTEGRITY ISSUES}

\section{A. Prudential Framework}

\section{Banking and microfinance sectors}

35. The prudential framework for the banking system has been strengthened but it is not yet fully in line with best international practices. Regulations on the minimum capital adequacy ratio, large exposures, and internal controls have been adopted since 2001 and a prudential framework for microfinance was introduced in 2002. However, the modalities for the calculation of the capital adequacy ratio fall short of the Basel Committee

\footnotetext{
${ }^{12}$ Regulations limit the aggregate net position to 45 percent of capital and the net position in a single currency to 15 percent. Compliance is spotty, controls are infrequent, and COBAC has no breakdown of positions by currency. Net long positions represent 1.8 percent of GDP; one local group holds one-third of the total position. Lack of relevant information did not allow an assessment of cross-currency exposures.

${ }^{13}$ As of December 31, 2005, public entities (central government, local administrations, and public agencies such as Social Security) hold CFAF 474 billion in banks, and state-owned enterprises hold CFAF 125 billion.
} 
recommendations, and its minimum level ( 8 percent) does not reflect risk levels in the CEMAC. The limit to large exposures ( 45 percent of regulatory capital) is also not consistent with the Basel Committee's recommended 25 percent, and it can even be up to 90 percent for companies that COBAC recognizes as strategically important for the countries. Finally, full provisioning for NPLs is only required after three to four years, which is too slow a pace.

\section{Compliance with the prudential norms is low, although there has been some} improvement in recent years. In November 2005, nearly one-fourth of the banks were in violation of the minimum capital adequacy ratio, and nearly three-fourths did not comply with the limits on large exposures. In addition, COBAC's severe understaffing has resulted in delays in drafting implementing regulations for prudential norms that have been recently passed (accounting and prudential consolidation, operational thresholds beyond which strengthened controls are required of auditors). COBAC's understaffing has also resulted in less frequent on-site inspections than desirable, and flaws in off-site supervision. ${ }^{14}$ Finally, COBAC's ability to impose sanctions is used too late, as evidenced by the long-lasting violations to critical norms (i.e., negative equity or large exposures amounting to several times a bank's capital).

37. The increasing gap between COBAC's missions and its resources is worrisome, as is the threat to its independence due to the role retained by the national authorities in banking supervision. ${ }^{15}$ COBAC has only four staff for off-site audits and eleven for on-site audits, while five experienced staff have recently left the agency. Despite the slight increase in staff since 2001, a serious lack of resources continues to hamper COBAC's work, a phenomenon exacerbated by the multiplication of tasks (i.e., supervision of microfinance, norms on internal controls and anti money laundering). COBAC's independence is also vulnerable due to the significant role that the finance ministries have retained in the issuance or withdrawal of bank licenses and the fact that most of the commissioners have official positions in the national ministries.

38. An action plan to update the regulatory framework must be prepared. There is a need to increase the institutional independence of COBAC by reducing further the role of the finance ministries in the licensing process, and ensuring a greater diversification of the COBAC's commissioners (which are mostly from the national finance ministries), and a doubling of the number of COBAC staff would be reasonable. COBAC needs to enforce sanctions as contemplated in current regulations to prevent banks from carrying out their activities without complying with the regulations. It would also be highly desirable to increase the minimum capital adequacy ratio so that it actually reflects the risks associated with the environment in which the banks are operating. Such a measure would help alleviate the exposure of banks' portfolio to risk concentration.

\footnotetext{
${ }^{14}$ On-site missions take place only every two to four years, and opportunities for in-depth exchanges between off-site supervisors and banks are limited.

${ }^{15}$ See also the ROSC evaluation of compliance with the BCP in the Annex.
} 
39. The regional regulations adopted by COBAC in 2002 for the supervision of microfinance institutions (MFIs), for implementation in 2007, follow international good practice. Nonetheless, most of the cooperative networks or federations are not able to consolidate or even aggregate the balance sheets of their members, or to supervise them correctly. Given the uneven development of MFIs, it would be difficult to apply uniform regional regulations. Furthermore, given the large number of MFIs to be licensed and COBAC's inadequate resources, there is a need to adopt a threshold for requiring a license that takes better account of risks, and to increase supervision capacity and resources at COBAC.

\section{Insurance sector}

40. The regional framework for the supervision of the insurance sector adopted in 1995 represented a clear improvement, but anecdotal evidence suggests that its effectiveness has deteriorated. In some cases, companies that are no longer viable have been allowed to continue in business, while in other cases the regional regulator approved the licensing of a new company, but national authorities did not grant the license in response to pressure from competitors. Several causes for this deterioration have been identified such as inadequate resources provided to the supervisor, ${ }^{16}$ political pressures on its staff (most of them are on secondment from their national authorities), a lack of clear delimitation of responsibilities between the regional supervisor and the national insurance authorities, and loopholes in the regulatory framework that excludes key areas such as the supervision of reinsurance and brokerage activities. Therefore, the plan to increase staffing levels and the capacity of the supervisors and to update the regulations is welcome. The independence of the supervisors needs also to be increased, for instance, by creating a dedicated group of inspectors.

\section{B. Deposit Insurance and Lender of Last Resort}

41. Although the BEAC has had to intervene occasionally as a lender of last resort, it has so far neither formally set up internal criteria for its interventions nor engaged in a review of the outcome of previous undertakings. The last large intervention of the BEAC took place in 2003 when it intervened to resolve a banking crisis in the CAR, mostly by quickly providing emergency liquidity and by suspending required reserves for the banks. The BEAC should undertake a review of its past interventions, with a view to assess their overall effectiveness and draw lessons for future intervention should the need arise.

42. A regional framework for the creation of a deposit insurance fund (FOGADAC) was adopted in January 2004. It defines the conditions for the calling of guarantees from FOGADAC, and assigns its administrative management to the national banking associations with a monitoring role for $\mathrm{COBAC}$, which is also expected to prepare implementing

\footnotetext{
${ }^{16}$ Insurance supervision is financed through levies on insurance premiums levied. However, it is estimated that less than one-third of the amount collected is allocated to the regional supervisor.
} 
regulations, in consultation with the banks. The mission considers that correcting the weaknesses affecting the prudential framework (particularly those related to the exercise of sanctioning powers) is a precondition to an implementation of the FOGADAC.

\section{Anti-Money Laundering and Combating the Financing of Terrorism}

43. The CEMAC regulation adopted in 2003 to set up a regional legal framework on Anti-Money Laundering and Combating the Financing of Terrorism (AML-CFT) constitutes a robust legal basis. The implementing regulation issued by the COBAC for the banking sector is a significant step forward, but the framework still needs further amendments to be in line with the standards and remains largely ignored outside of the banking sector. The predominance of cash-based transactions in the region makes it all the more essential to foster the implementation of AML-CFT obligations outside of the financial sector. More emphasis needs to be placed on the benefits of an effective AML-CFT framework, in terms of good governance, the fight against corruption and the trafficking of natural resources, so as to foster actions at the national level.

44. The unclear responsibilities between the regional agencies involved and the national authorities impedes an effective implementation of the framework. While leadership from regional agencies (i.e., BEAC and COBAC) is critical for momentum, the effectiveness of the AML-CFT framework requires a stronger commitment from national authorities. In particular, they need to take action to establish the national Financial Intelligence Units (FIUs) and build up their operational capacities, as well as to guarantee their independence and ensure the secure and confidential treatment of the information made available to them. The national authorities also need to pay attention to law enforcement and the judiciary, in order to properly investigate and prosecute suspicious transactions.

\section{Developing the Financial Sector}

\section{A. Access to Financial Services}

45. Access to financial services in the CEMAC is among the lowest in the world. With one million bank accounts and 780,000 customers of MFIs, the banks and MFIs show penetration rates of only 3 percent and 2.2 percent, respectively, of the population. Interest rate controls, by not encouraging savings mobilization or risk taking to expand lending, contribute to this as they in turn induce banks to set high minimum balances and management fees which discourage low-income individuals to open accounts. Low population density and limited purchasing power further create high operating costs, leading financial institutions to be concentrated in the most profitable areas. In addition, lack of financial data on potential borrowers and availability of credit registries, as well as significant weaknesses in the legal and judicial environment discourage the expansion of the customer base and lending to the private sector (see section B below). 
46. Few institutions provide financial services tailored to the needs of SMEs. ${ }^{17}$ The support SMEs receive generally goes through capacity building and guarantee programs supported by development partners or governments. Weak management and governance in SMEs, unreliable balance sheets, and the complexity of procedures for recording and enforcing guarantees are the major obstacles to increased financing, and few financial institutions seem to have the technical capabilities to assess the risk of SMEs and to design suitable financial services.

47. The microfinance sector provides uneven access across the CEMAC. The sector is well developed in Cameroon, Congo, and Chad, moderately developed in the CAR, and incipient in Gabon and Equatorial Guinea. The sector is concentrated around some 20 institutions (federations and networks), more than half of them in Cameroon. These large MFIs seem to have generally sound management and good financial results but they are fragile, especially given their rapid growth. Besides the large institutions, there are several hundred small institutions, very few of which seem profitable. Links between banks and MFIs are emerging, especially in Cameroon where a few banks have helped launch MFIs and are lending to them. However, some MFIs have difficulty opening bank accounts, as some banks view them as competitors or at-risk clients. Other than these links and sporadic refinancing of MFIs, only a few banks are considering expanding their services to them.

48. Several measures can help deepen financial intermediation and improve SMEs' access to funding. Eliminating the system of administrative interest rates would lift several obstacles to financial deepening. ${ }^{18}$ In the meantime, the authorities must ensure that the limits to lending and deposit rates are kept in line with market fundamentals. Given current market conditions, the floor on deposits rates should be lowered, and possibly indexed to a wholesale rate (i.e., below the BEAC policy rate), and the ceiling on lending rates should be increased without getting to usurious levels. SMEs access to funding would benefit from improving the legal and judicial systems, and creating credit history centers on SMEs.

\section{B. Strengthening Market Infrastructure}

\section{Legal and judicial framework}

49. The credit environment is governed by uniform OHADA legislation which is relatively modern, but perceived as complicated and not always well understood nor implemented. Weak governance, and limited training and specialization in judicial systems remain a major impediment to creditor rights' efficiency. Court proceedings are lengthy and unpredictable, and suffer from perceptions of malpractice and corruption. These shortcomings are problematic in a context where legal systems rely heavily on the formal judicial system to resolve disputes.

\footnotetext{
17 The best, but modest, response to SMEs needs is provided in Cameroon by a specialized credit institution, leasing companies, banks with strategies targeting SMEs, and some MFIs that are starting to serve SMEs.

${ }^{18}$ The authorities indicated that eliminating the lending rate ceiling depended on the introduction of usury laws.
} 
50. Lending activities are hampered by difficulties in formulating and implementing OHADA legislation on secured transactions. Banks typically consider secured interests on movables to be unreliable, while MFIs suffer from the complexity of the requirements and formalities involved. The lack of titled land and administrative bottlenecks in the operation of commercial registries limit the potential for the development of SME and housing finance.

\section{Debt collection and insolvency proceedings suffer from the complexity of} OHADA mechanisms and governance problems in the national judicial systems. The banks face problems in foreclosing of collateral and enforcing court decisions. In addition, insolvency procedures are rare and inefficient mostly due to the unreliability of insolvency administrators, who are neither regulated nor properly supervised.

\section{Measures to address weaknesses at national levels include:}

- Judicial systems. The training and specialization of judges in commercial, financial, and credit-related legal matters should be reinforced. Governance issues should be tackled through better enforcement of disciplinary measures, strengthening of inspection services, collegiality, and the publication of court decisions.

- Commercial and land registries. The operations of land and commercial registries should be improved. Commercial registries and archives should be run independently from general court records and cooperation with OHADA institutions should be strengthened to centralize data and computerize records.

- Insolvency administrators. A regulatory and supervisory framework should be adopted and include requirements for appointment, training, professional ethics, and discipline.

53. At the regional level, several OHADA uniform acts should be revisited. Enforcement procedures, especially fast-track measures for debt collection and foreclosure need to be revised in light of best practices. The regime for secured transactions should be reviewed to make collateral agreements more reliable and easier to implement. The draft OHADA uniform act on cooperatives should be revised, particularly to further simplify the rules on the creation, registration, and enforcement of collateral and to make this regime available to all credit providers (or at least all micro-credit providers). Finally, the insolvency regime should be reviewed with a view to buttress creditor rights and market discipline.

\section{Accounting and auditing}

54. The OHADA Accounting Framework places an excessive burden on SMEs. ${ }^{19}$ While it distinguishes levels of requirements according to company size, the thresholds have

\footnotetext{
${ }^{19}$ Findings are taken from a World Bank mission conducting an Accounting and Auditing ROSC in Cameroon. Given that many aspects of the accounting and auditing framework are common to all CEMAC member countries, these findings apply to a large extent to the whole CEMAC.
} 
not been revised, which makes SMEs subject to an excessive level of requirements. However, the consistency of the framework for large companies with the International Financial Reporting Standards (IFRS) should be strengthened over the medium term.

55. The lack of a standard for auditing practices raises serious concerns regarding the quality of financial statement audits. Adopting International Auditing Standards (ISA) would not only address weaknesses in the regulatory framework, but also contribute to improving the image of the accounting profession, which is generally not viewed favorably by the business community.

56. The financial information published by state-owned enterprises (SOEs) needs also significant strengthening. A review of the financial accounts of some large SOEs indicates a number of problems, and it appears that only very few SOEs publish their financial statements. Therefore, a unit in each country should be set up to monitor the publication of SOEs' financial accounts.

57. Banks should also be required to make their audited financial statements available to the public, as already done by some of them, to enhance market transparency. Strengthening the chart of account that applies to banks to ensure compliance with IFRS, after an appropriate transition period, would also help.

\section{Payment systems}

58. A regional payment system reform project under the aegis of the BEAC was launched in 2003 to make the national and regional payment systems more effective and secure. Implementation of the program has taken longer than originally anticipated due to a lack of experience, weak coordination, and some divergences with the banks regarding the interbank card system component of the project.

59. Several measures are needed to complete the project satisfactorily. A payment system management unit responsible for the implementation and supervision of the new system should be created at BEAC headquarters, supplemented by units in each country. In order to address the concerns expressed by the banks, consultation, communication, and dissemination of information on the reform program should be strengthened, and the recently created Coordination and Monitoring Committee should meet regularly (at least during the phase of implementation) to discuss and propose measures to address the concerns that future users may have with regard to some components of the reform program.

\section{Development Bank and Financial Market}

\section{Central African States Development Bank (BDEAC)}

60. The regional authorities have designated the BDEAC as a primary instrument for financing integration. Following financial difficulties, the BDEAC was restructured, with a view to strengthening corporate governance, reducing governments' influence in 
decision-making bodies, and enhancing risk control mechanisms. In order to ensure its financing, it was designated as the administrator of the Community Development Fund (FODEC) that would receive an annual allocation from tax and customs revenues. The BDEAC was also granted a revolving line of credit by the BEAC, and it has started mobilizing funds from the market.

61. The BDEAC should finalize the reforms it has initiated and resume its activities with prudence to avoid the errors of the past. The BDEAC still faces constraints on its operational and institutional plans, and the member states continue to be the predominant shareholders (holding more than 75 percent of the shares), discouraging the entry of new private shareholders. The corporate governance of the BDEAC should be strengthened further by, inter alia, establishing an independent and qualified Board of Directors. The current business strategy, which consists primarily of providing cofinancing with well-known lenders and refinancing of national financial institutions (sound banks and MFIs) seems prudent. For private lending, it would be desirable for the BDEAC to raise resources from the market to avoid creating distortions and to ensure its long-term viability. Finally, it will be important to monitor the solvency of the BDEAC, and the authorities should be prepared to close the bank if its activities do not prove to be viable.

\section{Securities exchanges}

62. Two independent and parallel securities exchanges are currently developing in the CEMAC, despite potential legal and financial conflicts. Cameroon is promoting the Douala Stock Exchange (DSX), and a regional securities exchange is being established in Libreville following a decision of the Conference of Heads of States. ${ }^{20}$ Despite the official inauguration of the DSX in 2003, this national market has not started trading yet, although the structures, mechanisms, and systems are ready to operate.

63. In order for the market to have a chance of being viable, the two exchanges should be merged and responsibility for its supervision unified. The parallel development of two competing institutions raises a number of legal questions, ${ }^{21}$ and the operation of both would not be viable considering the small size of the market. The authorities should also consider options for integration (at least partially as in cross listing) with other financial markets, particularly those in western Africa or South Africa. While awaiting an agreement on the merger of the two exchanges, any new investments that would involve a duplication of resources should be halted.

\footnotetext{
${ }^{20}$ The regional stock exchange was established in 2003, and the supervisory agency has been in operation since 2005. The regulatory framework is about to be finalized, the General Regulations for the market are being drafted; and decisions are about to be made regarding the trading and depository platforms to be used.

${ }^{21}$ Certain regional provisions are considered to have precedence over national laws. Hence, any financial operation conducted according to national provisions but in conflict with regional ones could be challenged.
} 


\section{Observance of Financial Sector Standards and Codes-Summary Assessments}

This Annex contains summary assessments of international standards and codes relevant for the financial sector. 1/ The assessments have helped to identify the extent to which the supervisory and regulatory is adequate to address the potential risks in the financial system. The following assessments of financial standards were undertaken:

- The Basel Core Principles for Effective Banking Supervision (BCP), by Cédric Mousset (World Bank) and Wafa Sfar (Banque Centrale de Tunisie).

- The IMF Code of Good Practices on Transparency in Monetary and Financial PoliciesTransparency of Banking Supervision, by Wafa Sfar (Banque Centrale de Tunisie).

The assessments were carried out during a visit to the CEMAC in January 2006. Additional information was added during the review process. They were based on the laws, regulations, policies and practices in place at the time the assessments were made, and on the following sources:

- Self-assessments by the supervisory authorities.

- Review of the relevant legislation, regulations, policy statements and other documentation.

- Interviews with the supervisory authorities, as well as credit institutions and external auditors.

1/ The assessment of the FATF Recommendations for Anti-Money Laundering Combating the Financing of Terrorism (AML/CFT) was undertaken by a World Bank team led by Jean Pesme, and comprising Isabelle Schoonwater and Marilyne Goncalves. The summary assessment will be issued to the Board in a separate document.

\section{Introduction}

\section{Basel Core Principles}

64. The assessment of the BCPs was conducted in accordance with "The Basel Core Principles for Effective Banking Supervision" (1997) and the "Core Principles Methodology" (1999). The assessment takes into account both the basis for regulation and supervision, as well as the implementation by the authorities and the supervised institutions.

\section{Institutional and legal framework for the financial sector: overview}

65. After the banking crisis of the mid-1980s, the authorities in the CEMAC countries decided at the start of the 1990s to implement uniform prudential standards for credit institutions throughout the region and to establish COBAC as the sole supervisory authority.

66. The banking sector accounts for the bulk of the financial sector in CEMAC. There are three types of credit institution (CI) in CEMAC: 33 banks, 17 financial institutions, and over 1,000 microfinance institutions (MFI). Banks alone account for almost 90 percent of total CI assets and deposits. 


\section{Prior conditions for effective banking supervision}

67. The economic environment in CEMAC is characterized by a preponderance of the primary sector, which accounts for over half its GDP and much of its volatility. The recent increase in oil prices translated into a strong increase in bank deposits. Given the high interest paid on deposits, limited perceived opportunities for lending, and low remuneration of required reserves, there was a decline in credit institutions' profitability in 2005.

68. The legal and judicial environment has been a constraint on the development of banking in CEMAC. While the shortcomings of the legal framework have been partially overcome in recent years, the conditions for enforcing the law remain highly problematical. The reasons for this are said to be, in particular, underfunding of the justice system, insufficient training for judges, lack of specialization, and even, in some cases, corruption.

69. The accounting framework in force is that established by OHADA, mainly in the 1990s. The outside auditor profession is still incipient and this is reflected in the poor quality of the work of some members of the profession.

70. The idea of establishing a Central African Deposit Guarantee Fund (FOGADAC) dates back to 1996, and the CEMAC regulation instituting FOGADAC was adopted in 2004, but is has not yet been implemented. The conditions under which the FOGADAC will be introduced will determine its ability to fulfill its mission. The preamble to the CEMAC regulation reiterates that the effectiveness of COBAC action determines that of FOGADAC. Correcting the weaknesses affecting the prudential framework thus constitutes a precondition to an effective implementation of the FOGADAC (particularly those related to CI monitoring and the exercise of sanctioning powers). In addition, the operation of FOGADAC will require increased transparency in credit institutions. Finally, its methods of operation will have to be carefully defined (guarantee ceilings, financing methods, determination of risk based premia, intervention criteria, and conditions for monitoring by COBAC).

\section{Summary}

71. The regulatory framework has been updated following the assessment mission of 2001. However, the core prudential regulations (capital adequacy ratio, large exposures, and provisioning) are still much less demanding than in international standards. Apart from the shortcomings of the regulatory requirements, compliance with certain regulations is weak (especially capital adequacy ratio, large exposures, and internal control). COBAC does not fully enforce implementation of the regulations, which alters its credibility and the effectiveness of its supervision. For instance, COBAC appears to make use of its powers to impose sanctions too late, with serious breaches of regulations persisting for several years (negative equity, or risk on a single borrower equivalent to two or three times an institution's own funds).

72. The aforementioned difficulties stem largely from a growing gap between COBAC's mandates and its resources, a weakness already noted in 2001. Action by COBAC may also 
in certain cases depend on decisions taken by national finance ministries, which play a pivotal role in licensing and make up most of COBAC's commissioners.

73. In 2003, COBAC decided to gradually implement Basel 2 in the CEMAC. At that time, it assumed that full compliance with the BCP would be achieved by end 2004 and contemplated introducing the simplified standardized approach in 2008 and the other credit risk approaches by 2013. COBAC has engaged in first steps regarding the implementation of Basel 2, including training of its staff, although Basel 2 is unlikely to begin being introduced by 2008 as initially planned.

74. Correcting the shortcomings of the prudential framework, and, more broadly, of the institutional environment, is a prerequisite for the gradual implementation of some of the provisions of the new Basel 2 Capital Accord, an objective which in the short term should not divert limited resources from more urgent supervisory actions. Implementing that Accord should not be contemplated until COBAC is really in a position to perform the core functions currently assigned to it and satisfactory steps have been taken to remedy the legal, judicial, and accounting shortcomings detected during the FSAP.

\section{Objectives, Autonomy, Powers, and Resources (CP 1)}

75. The COBAC is the only body responsible for supervising $\mathrm{CI}$ in the CEMAC countries. Even more markedly than in 2001, a shortage of staff seriously impairs COBAC's ability to ensure that regulations are implemented and, more generally, a satisfactory exercise of its supervisory functions. Moreover, the preponderance of representatives of the finance ministries in COBAC's executive body undermines its independence.

\section{Licensing and Structure (CPs 2-5)}

76. There are three types of licenses: national licenses to operate as a credit institution and as a micro-finance institution and the single license for the CEMAC created in 2000 (no request for such a license has yet been submitted to COBAC). National finance ministries play a central role in the granting and withdrawal of national licenses. For instance, applications for national licenses have to be submitted to national ministries of finance which have to forward them to the COBAC to obtain its approval, but without being bound by a time limit. Appeals by national finance ministries against license withdrawal decided by the COBAC have the automatic effect of suspending the sanction. In exceptional circumstances, a national finance ministry refused to implement regional regulations and grant a license which had been cleared by COBAC.

\section{Prudential Regulations and Requirements (CPs 6-15)}

77. The main prudential regulations (capital adequacy ratio, large exposures, and provisioning) are still much less demanding than international standards. For instance, the conditions governing the calculation of the capital adequacy ratio are in many cases less stringent than the Basel Committee's recommendations, while the minimum ratio, which has 
been gradually moved to 8 percent, does not reflect existing levels of risk in CEMAC. As for large exposures, institutions can lend up to 45 percent of their own funds to a single borrower, and as much as 90 percent to companies that COBAC recognizes as being of national importance, whereas the ceiling recommended by the Basel Committee in order to ensure the ongoing viability of institutions following defaults on their major risks is 25 percent. Finally, provisioning rules do not contemplate 100 percent principal provisioning until a loan has been nonperforming for three to four years, which appears to be an excessive length of time.

\section{Methods of Ongoing Supervision (CPs 16-20)}

78. COBAC does not fully enforce the existing regulations, which alters its credibility and effectiveness. There are several examples of difficulties in drafting rules governing the implementation of regulations (consolidation of accounting and prudential standards, thresholds above which external auditors are required to perform additional verifications etc.). Other than in crisis situations, its controls are also too infrequent (on-site inspections carried out only once every two to four years, only exceptional opportunities for in-depth dialogue between the Ongoing Supervision Directorate and the credit institutions, too limited verification of the quality of accounting and prudential statements etc.).

79. The aforementioned difficulties stem largely from a growing gap between COBAC's mandates and its resources. COBAC only employs 39 officers, including 4 engaged in ongoing supervision and 11 in on-site inspections. In addition, 5 experienced staff members have recently left the COBAC. The slight increase in its staff since 2001 neither matches the COBAC's lack of resources nor the expansion of its mandates (supervision of a large number of MFI, internal control, prevention of money laundering, and combating the financing of terrorism). An ambitious plan to boost staff levels over the medium term is indispensable; a reasonable goal might be to double the number of officers currently assigned to COBAC.

\section{Information Requirement (CP 21)}

80. COBAC is in charge of setting accounting standards for CI, which it has done in several regulations which largely transpose OHADA rules. However, some of these relations are not yet implemented for lack of the necessary instructions which COBAC has to issue. Even though regulations place large responsibilities on CI's external auditors, COBAC does not yet efficiently use its powers to ensure that they properly discharge their duties.

\section{Formal Powers of Supervisors (CP 22)}

81. Apart from the intrinsic shortcomings of the regulatory requirements, compliance with certain regulations is weak. Nearly a quarter of the banks were in breach of the minimum capital adequacy ratio at end-November 2005, and nearly three quarters were not complying with large exposures rules. Although it entered into effect in 2003, the regulation on internal control was still very unevenly applied in early 2006. 
82. While, generally speaking, COBAC has adequate powers to impose sanctions, it appears that in certain cases it resorts to them too late, after the failure of numerous restructuring plans. In particular, no disciplinary license withdrawal has been called for since 1999, although five CI posted negative equity at the time of the mission. Such a situation alters the conditions of competition among CI and hence the stability of the banking system. It also strongly impairs the credibility of the actions that COBAC undertakes.

\section{Cross-Border Banking (CPs 23-25)}

83. A large fraction of the banking system is made of subsidiaries of foreign banking groups, most of them French. COBAC has established very close cooperation ties with the French Banking Commission (exchanges of individual pieces of information, training in France for certain officers...). Few CEMAC banks have operations abroad.

Table 3. Recommended Action Plan to Improve Compliance of the Basel Core Principles

\begin{tabular}{|l|l|}
\hline \multicolumn{1}{|c|}{ Principle } & \multicolumn{1}{c|}{ Action Recommended } \\
\hline $\begin{array}{l}\text { 1. Objectives, } \\
\text { Autonomy, Powers, } \\
\text { and Resources }\end{array}$ & $\begin{array}{l}\text { Significantly strengthen the staff of COBAC, preferably doubling the number of } \\
\text { personnel over the medium term. Strengthen COBAC's independence and diversify } \\
\text { the origin of its commissioners. Introduce rules for the winding-up of CI. }\end{array}$ \\
\hline 3. Licensing criteria & $\begin{array}{l}\text { Review conditions for licensing applications for credit institutions, senior } \\
\text { management and external auditors (especially concerning the role of the national } \\
\text { finance ministries in the granting and withdrawal of licenses). }\end{array}$ \\
\hline $\begin{array}{l}\text { 5. Acquisitions and } \\
\text { investments }\end{array}$ & $\begin{array}{l}\text { Impose an obligation to report acquisition plans so that COBAC can oppose them } \\
\text { or establish the conditions on which they may take place. }\end{array}$ \\
\hline 6. Capital adequacy & $\begin{array}{l}\text { Increase gradually the minimum capital adequacy ratio above 8 percent. Update the } \\
\text { regime (i.e., risk weights) to comply with Basel Committee recommendations. }\end{array}$ \\
\hline $\begin{array}{l}\text { 8. Evaluation of assets } \\
\text { and provisions }\end{array}$ & Gradually shorten automatic provisioning deadlines. \\
\hline 9. Large exposures & $\begin{array}{l}\text { Reduce the large exposure limit from 45 percent to 25 percent, as recommended by } \\
\text { the Basel Committee. Eliminate the provisions which increase the limit to 90 } \\
\text { percent for certain companies recognized as strategic. }\end{array}$ \\
\hline $\begin{array}{l}\text { 10. Monitoring of } \\
\text { connected lending }\end{array}$ & Expand the definition of connected persons. \\
\hline 12. Market risk & Introduce a regulatory framework. \\
\hline 14. Internal control & $\begin{array}{l}\text { Conduct the internal control inspections scheduled for 2006 and ensure that the } \\
\text { follow-up guarantees that all institutions effectively implement current regulations. }\end{array}$ \\
\hline $\begin{array}{l}\text { 18. Supervision on solo } \\
\text { and consolidated basis }\end{array}$ & $\begin{array}{l}\text { Issue the instructions required to implement existing regulations on a solo and on a } \\
\text { consolidated basis. }\end{array}$ \\
\hline 22. Remedial measures & $\begin{array}{l}\text { Ensure that COBAC's powers to impose sanctions on CI, senior management and } \\
\text { external auditors are effectively used when serious breaches are detected. Examine } \\
\text { the advisability of adopting a more "automatic" license withdrawal procedure when } \\
\text { a CI's condition remains critical for too long. }\end{array}$ \\
\hline
\end{tabular}




\section{The authorities' response}

84. The CEMAC ${ }^{22}$ authorities mentioned the key measures planned in response to the assessment, and they pointed out certain areas where there is a difference of opinion, as elaborated below.

85. The key measures planned in response to the assessment are the following: (i) some of the staff recruited at end-2005 by BEAC will be assigned to COBAC; (ii) amendments to the capital adequacy ratio and large exposure regulations may be contemplated after discussion with the industry, while updated regulations would in most cases not start being implemented before 2008; (iii) instructions required to implement existing regulations will be issued by end-2006; and (iv) generally speaking, the "underdevelopment of the banking system and the impact of the withdrawal of bank licenses on economic agents, particularly in the absence of an operational mechanism of deposit insurance, calls for some caution in withdrawing licenses."

86. The CEMAC authorities noted areas in which they begged to differ with the assessors. They indicated that, regarding the issuance and withdrawal of licenses, ministers of finance are considered to have no discretionary power, although plans are being made to amend the texts to reflect the assessment's recommendations in this matter. They also indicated that the minimum mandatory provisioning times are considered to be appropriate to the CEMAC legal environment. Finally, they consider unnecessary for credit institutions and States to be included among possible connected parties.

\section{IMF's TRANSPARENCY CODE-TRANSPARENCY OF BANKING SUPERVISION}

\section{Principal conclusions and recommendations}

87. All treaties, conventions, and regulations affecting the community are posted on the Internet, but not all COBAC regulations. There are well established procedures for formulating and accounting for financial policies, but they could benefit from clarification of the procedures for renewing the governor and Deputy Governor's terms and the criteria for dismissing members of COBAC, as well as from publication of the information exchange agreements signed with foreign supervisory authorities.

88. The presentation of the data regarding policies and implementation of banking supervision is ineffective given that BEAC's annual report and that of COBAC are published with a two-year lag. The COBAC bulletin has not been published since September 2003. Nevertheless, its annual report up to that time include descriptions of the Commission's objectives and of the efforts and resources deployed to attain them, as well as aggregate

\footnotetext{
${ }^{22}$ BEAC, COBAC, BDEAC, and GABAC (Task Force against Money Laundering in Central Africa).
} 
statistics on the financial situation of the sector. The transparency of measures adopted to guarantee the integrity of the financial agency could also be enhanced.

89. The objectives and responsibilities for banking supervision are clear, and the Conventions and some of the regulations are posted on the BEAC and COBAC websites. The implementation of banking supervision and reporting of information should in theory be transparent. However, that would require that public disclosure of financial policy decisions and publication of the annual report is regular and punctual. Delays on the part of the COBAC in publishing the annual reports alter the credibility of those bodies and impair the transparency of the process of announcing and acceding to information on financial policy.

90. The COBAC report is submitted to the Ministerial Committee of the Central African Monetary Union and to the Conference of Heads of States. The internal verification mechanism is however no longer disclosed.

\section{Recommended action plan}

91. The following actions could usefully be implemented:

- $\quad$ Post all banking supervision regulations on the Internet website.

- $\quad$ Clarify the procedures governing the renewal of the terms of office of the governor and deputy governor and the criteria for removing members of COBAC.

- $\quad$ Publish the information exchange agreements between COBAC and similar supervisory agencies in foreign countries.

- $\quad$ Restore publication of the annual report of BEAC and that of COBAC with a reasonable time lag, as well as publication of COBAC's periodic bulletin.

- Include in BEAC's annual report data on changes in the payment system and on risk management policy in relation to it.

\section{The authorities' response}

92. The CEMAC authorities were in broad agreement with the evaluation. 


\section{Stress Test Methodology and Results}

\section{A. Stress Tests Methodology}

93. The shocks at end-December 2005 were tested on individual data (33 banks) for the entire CEMAC, for each country, and for three groups of banks: foreign banks ( 55 percent of assets), local banks, and local bank groups (26 percent of assets).

\begin{tabular}{llc}
\hline & \multicolumn{1}{c}{ Credit Risk Shocks } & Provisioning Rate \\
\hline Loan concentration & 1. Default of largest corporate borrower & $75 \%$ \\
& 2. $25 \%$ of loans to oil and gas sectors become doubtful & $75 \%$ \\
& $\begin{array}{l}\text { 3. 40\% of loans to forestry sector and 20\% of loans to } \\
\text { transport sector become doubtful }\end{array}$ & $75 \%$ \\
Overall credit risk & 4. Migration from unpaid to doubtful loans & $75 \%$ \\
& 5. 50\% increase in doubtful loans & COBAC rate over 3-years \\
Credit risk linked & 6. Deterioration of convergence criteria 1/ & none \\
to fiscal & 7. Government default on bank loans & $15 \%$ \\
performances & 8. Government default on bank loans and securities & $15 \%$ \\
& 9. Shock (8) + 20\% of loans to public enterprises become & $15 \%$ \\
& doubtful + indirect effects of government arrears on & \\
& wages affecting half of civil servants that are bank & \\
\hline
\end{tabular}

1/ The weight on banks' loans to governments rises from 75 percent to 100 percent for Congo; from 50 percent to 75 percent for Cameroon, Gabon, and Chad; and from 20 percent to 50 percent for Equatorial Guinea.

94. Exchange risk. In view of the significant exposure of the CEMAC economic region to external commodity price shocks, four sensitivity tests were run: (i) 40 percent depreciation of the CFA relative to the euro; (ii) 20 percent appreciation of the CFA relative to the euro; (iii) 40 percent depreciation of the euro relative to the U.S. dollar; and (iv) 40 percent appreciation of the euro relative to the U.S. dollar. Given the lack of information on the currency composition of banks' foreign exchange positions, assumptions were made regarding the relative shares of U.S. dollars and euros.

95. Liquidity risk. Two shocks were assessed: (i) 25 percent drop in deposits (a 25 percent drop had been recorded at the time of the bank crises in Cameroon); (ii) 50 percent decline in term deposits of the central government and a decline in all of the central government's demand deposits. The tests measured: (i) the impact on a liquidity ratio calculated by the mission; and (ii) the impact on the resources which banks could mobilize to cope with shocks (cash, liquidity at the BEAC, foreign exchange positions, and excess reserves).

96. Interest rate risk. As the maturity mismatch between bank assets and liabilities is limited, the impact of any increase in interest rates on portfolio valuations would be limited, although not insignificant. However, the analysis of the impact of an increase in interest rates is obscured by the lack of effective mechanisms for the transmission of monetary policy. It is 
accordingly difficult to assess which rate - among those set by the BEAC - has the most significant impact on bank balance sheets.

\section{B. Stress Tests Results}

\section{Appendix Table 1. Changes in Capital Adequacy Ratio}

\begin{tabular}{|c|c|c|c|c|c|c|c|c|c|c|}
\hline (Changes in capital adequacy ratio) & Cameroon & CAR & Congo & Gabon & $\begin{array}{c}\text { Equa. } \\
\text { Guinea }\end{array}$ & Chad & CEMAC & $\begin{array}{c}\text { Foreign } \\
\text { banks }\end{array}$ & $\begin{array}{l}\text { Local } \\
\text { banks }\end{array}$ & $\begin{array}{c}\text { Local } \\
\text { groups }\end{array}$ \\
\hline Capital adequacy ratio & 11.2 & 12.4 & 15.9 & 23.3 & 13.0 & 15.3 & 14.8 & 16.0 & 13.1 & 11.6 \\
\hline \multicolumn{11}{|l|}{ Capital adequacy ratio after shocks } \\
\hline \multicolumn{11}{|l|}{ A. Credit risk } \\
\hline Default largest individual risk & 5.4 & 3.4 & 3.4 & 14.7 & 1.7 & -3.1 & 6.6 & 9.3 & 4.0 & 3.4 \\
\hline \multicolumn{11}{|l|}{ Sectoral shocks } \\
\hline Petroleum and gas sector & n.d. & 11.5 & 15.4 & 23.0 & 12.8 & n.d. & 14.7 & 15.9 & 12.9 & 11.5 \\
\hline Forestry sector & n.d. & 12.4 & 13.8 & 19.7 & 12.1 & n.d. & 13.7 & 14.6 & 12.4 & 10.5 \\
\hline Reclassification of loans in one category & 10.0 & 10.3 & 15.6 & 22.6 & 12.4 & 14.9 & 13.9 & 15.3 & 11.9 & 10.6 \\
\hline $50 \%$ increase in NPLs & 6.7 & 3.2 & 15.5 & 19.8 & 11.0 & 9.1 & 10.8 & 11.5 & 9.5 & 9.4 \\
\hline Deterioration convergence criteria & 11.1 & 12.4 & 15.8 & 22.8 & 12.9 & 14.7 & 14.7 & 15.8 & 13.1 & 11.5 \\
\hline Default on govt. loans & 11.0 & 10.7 & 15.3 & 21.5 & 12.5 & 12.3 & 14.0 & 15.1 & 12.6 & 11.0 \\
\hline Default on govt. loans and securities & 9.3 & 10.1 & 15.3 & 19.8 & 12.6 & 12.2 & 12.7 & 13.0 & 12.2 & 10.4 \\
\hline Default on govt. + salary arrears & 9.3 & 9.9 & 15.2 & 19.6 & 12.5 & 12.2 & 12.6 & 12.8 & 12.2 & 10.3 \\
\hline \multicolumn{11}{|l|}{ B. Exchange risk } \\
\hline $40 \%$ depreciation against the euro & 17.7 & 13.9 & 35.3 & 42.7 & 20.8 & 18.4 & 24.9 & 16.0 & 24.8 & 27.1 \\
\hline $20 \%$ appreciation against the euro & 7.9 & 11.6 & 6.1 & 13.6 & 9.1 & 13.7 & 9.8 & 11.4 & 7.3 & 3.9 \\
\hline $40 \%$ depreciation against the dollar & 11.8 & 12.7 & 17.8 & 31.0 & 16.9 & 16.5 & 17.6 & 18.3 & 16.6 & 16.5 \\
\hline $40 \%$ appreciation against the dollar & 9.9 & 12.1 & 12.0 & 19.4 & 11.5 & 14.6 & 12.8 & 13.7 & 11.4 & 6.7 \\
\hline \multicolumn{11}{|l|}{ C. Interest rate risk } \\
\hline Yield curve: +500 basis points & 6.8 & 11.7 & 14.7 & 20.0 & 10.8 & 12.7 & 11.3 & 11.4 & 10.9 & 8.8 \\
\hline Increase in short-term rates & 6.8 & 11.7 & 14.7 & 19.9 & 10.7 & 12.6 & 11.3 & 11.3 & 10.8 & 8.8 \\
\hline \multicolumn{11}{|l|}{ D. Liquidity risk } \\
\hline Liquidity ratio $1 /$ & 76.8 & 98.3 & 96.7 & 80.8 & 91.1 & 89.4 & 82.7 & 74.2 & 92.8 & 92.2 \\
\hline \multicolumn{11}{|l|}{ Liquidity ratios after shocks } \\
\hline $25 \%$ withdrawal on all deposits & 69.0 & 97.7 & 95.6 & 74.4 & 88.1 & 85.8 & 76.9 & 65.6 & 90.4 & 89.6 \\
\hline $50 \%$ reduction of public sector deposits & 75.9 & 98.2 & 96.4 & 79.7 & 89.8 & 88.7 & 81.6 & 73.1 & 92.1 & 91.7 \\
\hline \multicolumn{11}{|l|}{ E. Combination of shocks scenario } \\
\hline Interest rate + govt. default & 5.0 & 9.5 & 14.2 & 16.5 & 10.4 & 9.7 & 9.3 & 8.4 & 9.9 & 7.5 \\
\hline USD appreciation + oil + govt. default & n.d. & 9.6 & 11.0 & 17.4 & 10.8 & n.d. & 11.9 & 12.7 & 10.6 & 5.9 \\
\hline Interest rate + increase in NPLs & 2.4 & 2.6 & 14.3 & 16.5 & 8.8 & 6.6 & 7.4 & 7.0 & 7.2 & 6.6 \\
\hline Increase in NPLs + govt. default & 6.5 & 1.6 & 15.0 & 18.1 & 10.5 & 6.2 & 10.0 & 10.6 & 9.0 & 8.8 \\
\hline
\end{tabular}

Source: COBAC and mission estimates. 1/Ratio of assets and liabilities with remaining term of less than one month calculated by COBAC.

Appendix Table 2. Capital Shortfall in Percent of GDP

\begin{tabular}{lcccc}
\hline & \multicolumn{2}{c}{ Default Largest Individual Risk } & \multicolumn{2}{c}{ Appreciation of 20 Percent of Currency } \\
Against Euro
\end{tabular}


Statistical Appendix. Table 1. Selected Economic and Financial Indicators, 2000-05

\begin{tabular}{|c|c|c|c|c|c|c|}
\hline & 2000 & 2001 & 2002 & 2003 & 2004 & 2005 Est. \\
\hline & \multicolumn{6}{|c|}{ (Annual percentage change) } \\
\hline \multicolumn{7}{|l|}{ National income and prices } \\
\hline GDP at constant prices & 3.3 & 8.1 & 4.8 & 4.6 & 8.4 & 4.3 \\
\hline Oil GDP 1/ & -0.3 & 12.1 & 5.1 & 5.4 & 17.1 & 4.3 \\
\hline Non-oil GDP 1/ & 4.8 & 6.4 & 4.7 & 4.2 & 4.4 & 4.2 \\
\hline Terms of trade & 26.2 & -5.6 & 2.9 & 4.9 & 0.9 & 15.8 \\
\hline Nominal effective exchange rate & -5.2 & 0.7 & 2.4 & 5.8 & 2.9 & -0.2 \\
\hline \multirow[t]{2}{*}{ Real effective exchange rate } & -7.5 & 3.0 & 4.0 & 5.2 & 1.8 & 1.4 \\
\hline & \multicolumn{6}{|c|}{ (Annual changes in percent of beginning-of-period broad money) } \\
\hline \multicolumn{7}{|l|}{ Money and credit } \\
\hline Broad money & \multicolumn{6}{|c|}{ (In percent of GDP, unless otherwise indicated) } \\
\hline \multicolumn{7}{|l|}{ National accounts } \\
\hline Gross domestic savings & 37.7 & 36.1 & 26.2 & 37.0 & 39.4 & 47.2 \\
\hline Gross domestic investment & 21.6 & 27.8 & 25.2 & 27.3 & 24.2 & 22.6 \\
\hline \multicolumn{7}{|l|}{ Government financial operations } \\
\hline Total revenue, excluding grants & 21.4 & 22.9 & 20.9 & 20.5 & 21.1 & 25.8 \\
\hline Government expenditure & 18.6 & 21.3 & 21.2 & 20.3 & 19.3 & 17.9 \\
\hline Primary basic fiscal balance 2 / & 9.9 & 9.7 & 6.2 & 7.0 & 7.2 & 13.7 \\
\hline Basic fiscal balance 3/ & 5.6 & 5.1 & 2.4 & 2.7 & 4.3 & 10.1 \\
\hline Overall fiscal balance, excluding grants & 2.8 & 1.6 & -0.3 & 0.2 & 1.8 & 7.9 \\
\hline Current account, including grants & 3.2 & -6.6 & -10.5 & -7.0 & -3.1 & 2.7 \\
\hline External public debt & 84.6 & 82.7 & 71.2 & 68.2 & 59.8 & 40.6 \\
\hline \multicolumn{7}{|l|}{ Gross official reserves (end of period, } \\
\hline in millions of U.S. dollars) & $1,318.9$ & $1,143.3$ & $1,678.2$ & $1,908.3$ & $3,188.7$ & $5,315.7$ \\
\hline In months of imports of goods and services & 1.9 & 1.4 & 1.8 & 1.6 & 2.4 & 3.9 \\
\hline \multicolumn{7}{|l|}{ Memorandum items: } \\
\hline Nominal GDP (in billions of CFA francs) & 15,030 & 15,756 & 16,700 & 17,431 & 19,895 & 23,140 \\
\hline CFA francs per U.S. dollar, average & 712.0 & 733.0 & 697.0 & 581.2 & 528.3 & 526.6 \\
\hline Oil prices (in U.S. dollars per barrel) & 28.2 & 24.3 & 25.0 & 28.9 & 37.8 & 53.4 \\
\hline Oil prices (in CFA francs per barrel) & 20,103 & 17,835 & 17,390 & 16,793 & 19,947 & 28,096 \\
\hline
\end{tabular}

Sources: IMF, World Economic Outlook database; and staff estimates and projections. 1/ The weighted average of oil and non-oil real GDP growth rates does not always add up to real GDP growth because of the nonadditivity of the underlying index. 2/ Excluding grants and foreign-financed investment and interest payments. 3/ Excluding grants and foreign-financed investment. 4/ Percent of non-oil GDP. 
Statistical Appendix. Table 2. Margins on Total Earning Assets-TEA, 2002-04 (In percent, unless otherwise indicated)

\begin{tabular}{|c|c|c|c|c|c|c|c|c|c|c|c|c|c|c|}
\hline & \multicolumn{2}{|c|}{ Cameroon } & \multicolumn{2}{|c|}{ CAR } & \multicolumn{2}{|c|}{ Congo } & \multicolumn{2}{|c|}{ Gabon } & \multicolumn{2}{|c|}{ Eq. Guinea } & \multicolumn{2}{|c|}{ Chad } & \multicolumn{2}{|c|}{ CEMAC } \\
\hline & 2002 & 2004 & 2002 & 2004 & 2002 & 2004 & 2002 & 2004 & 2002 & 2004 & 2002 & 2004 & 2002 & 2004 \\
\hline TEA (billion)1/ & 1,063 & 1,201 & 58 & 65 & 175 & 153 & 735 & 743 & 124 & 118 & 104 & 132 & 2,259 & 2,411 \\
\hline Gross margin 2/ & 8.4 & 8.0 & 11.1 & 8.3 & 11.2 & 9.3 & 9.1 & 8.6 & 13.4 & 10.0 & 12.6 & 9.6 & 9.8 & 8.5 \\
\hline NPLs provisioning & 0.9 & 0.8 & 2.2 & 2.4 & 0.0 & 0.1 & 0.6 & 0.8 & 0.3 & 0.8 & 1.3 & 1.1 & 0.8 & 0.8 \\
\hline Net margin & 7.5 & 7.1 & 8.9 & 5.9 & 11.2 & 9.2 & 8.5 & 7.8 & 13.1 & 9.2 & 11.3 & 8.5 & 9.1 & 7.7 \\
\hline Other income net $3 /$ & 5.5 & 9.5 & 10.3 & 9.2 & 10.2 & 9.1 & 10.4 & 9.3 & 9.5 & 14.6 & 13.4 & 13.0 & 8.2 & 9.9 \\
\hline Total margin & 13.0 & 16.7 & 19.2 & 15.1 & 21.4 & 18.3 & 19.0 & 17.2 & 22.7 & 23.8 & 24.7 & 21.5 & 17.2 & 17.6 \\
\hline Overhead expenses & 1.8 & 2.9 & 3.1 & 3.1 & 3.3 & 3.3 & 2.4 & 2.6 & 3.2 & 4.6 & 4.7 & 5.1 & 2.4 & 3.0 \\
\hline Personnel expenses & 1.4 & 2.3 & 2.1 & 2.0 & 2.5 & 2.7 & 2.8 & 3.2 & 1.5 & 2.0 & 3.2 & 3.5 & 2.0 & 2.6 \\
\hline Margin before taxes & 9.8 & 11.5 & 14.0 & 9.9 & 15.7 & 12.2 & 13.8 & 11.4 & 18.0 & 17.2 & 16.8 & 12.8 & 12.8 & 11.9 \\
\hline Taxes & 0.4 & 1.2 & 0.2 & 0.4 & 0.6 & 0.7 & 0.8 & 1.5 & 0.4 & 0.7 & 0.7 & 1.1 & 0.6 & 1.2 \\
\hline Margin after taxes & 9.4 & 10.3 & 13.8 & 9.5 & 15.1 & 11.6 & 13.0 & 9.9 & 17.6 & 16.5 & 16.1 & 11.7 & 12.3 & 10.7 \\
\hline Return on assets-ROA & 1.3 & 1.2 & 3.0 & 2.8 & 1.9 & 2.1 & 3.7 & 2.9 & 2.1 & 1.1 & 2.8 & 2.0 & 2.2 & 1.8 \\
\hline Return on equity-ROE & 18.9 & 13.9 & 201. & 19.9 & 42.7 & 27.0 & 20.2 & 17.9 & 29.0 & 16.2 & 22.0 & 17.2 & 21.0 & 16.9 \\
\hline
\end{tabular}

Source: COBAC and staff estimates. 1/ TEA include securities, interbank and customers' loans. 2/ Gross margin is difference between average return on TEA and average cost of funds. 3/ Includes net income on opérations de clientèle, opérations de trésorerie, and opérations sur crédit-bail.

Statistical Appendix. Table 3. Selected Financial Soundness Indicators, 2002-05 (In percent)

\begin{tabular}{|c|c|c|c|c|c|c|c|c|c|c|c|c|c|c|}
\hline & \multicolumn{2}{|c|}{ Cameroon } & \multicolumn{2}{|c|}{ CRA } & \multicolumn{2}{|c|}{ Congo } & \multicolumn{2}{|c|}{ Gabon } & \multicolumn{2}{|c|}{ Eq. Guinea } & \multicolumn{2}{|c|}{ Chad } & \multicolumn{2}{|c|}{ CEMAC } \\
\hline & 2002 & 2005 & 2002 & 2005 & 2002 & 2005 & 2002 & 2005 & 2002 & 2005 & 2002 & 2005 & 2002 & 2005 \\
\hline \multicolumn{15}{|l|}{ Capital adequacy ratio } \\
\hline Weighted ratio $1 /$ & 9.3 & 9.3 & 7.1 & 12.1 & 4.3 & 6.4 & 18.9 & 14.3 & 3.9 & 12.0 & 8.7 & 11.9 & 11.4 & 10.8 \\
\hline Weighted ratio $2 /$ & & 11.2 & & 12.4 & & 15.9 & & 23.3 & & 13.0 & & 15.3 & & 14.8 \\
\hline Capital/assets & 7.1 & 8.7 & 14.8 & 14.2 & 4.4 & 8.0 & 18.1 & 16.4 & 7.2 & 7.0 & 12.8 & 11.6 & 10.5 & 10.8 \\
\hline \multicolumn{15}{|c|}{ Asset quality, profitability and liquidity } \\
\hline Gross NPL/gross loans & 15.8 & 12.6 & 31.0 & 34.2 & 1.1 & 3.4 & 11.3 & 14.3 & 8.7 & 17.2 & 19.6 & 13.7 & 13.9 & 13.7 \\
\hline Net NPLs/gross loans & 3.0 & 1.8 & 7.8 & 7.5 & 0.9 & 0.5 & 3.8 & 2.9 & 2.3 & 5.7 & 4.2 & 2.9 & 3.4 & 2.6 \\
\hline Net NPLs/capital & 23.0 & 11.8 & 45.2 & 50.8 & 7.8 & 1.9 & 14.2 & 8.1 & 13.0 & 24.0 & 19.6 & 16.8 & 18.2 & 11.6 \\
\hline Assets return (ROA) & 1.3 & 1.2 & 3.0 & 2.8 & 1.9 & 2.1 & 3.7 & 2.9 & 2.1 & 1.1 & 2.8 & 2.0 & 2.2 & 1.8 \\
\hline Equity return (ROE) & 18.9 & 13.9 & 20.1 & 19.9 & 42.7 & 27.0 & 20.2 & 17.9 & 29.0 & 16.2 & 22.0 & 17.2 & 21.0 & 16.9 \\
\hline Liq. assets/total assets & 22.1 & 18.9 & 2.7 & 7.0 & 13.6 & 51.2 & 6.3 & 14.2 & 14.8 & 39.2 & 22.4 & 15.3 & 16.0 & 22.1 \\
\hline Liq. assets/demand deposits & 35.8 & 33.4 & 6.7 & 13.1 & 33.7 & 74.0 & 35.0 & 32.4 & 22.2 & 44.2 & 10.8 & 26.9 & 29.3 & 38.5 \\
\hline
\end{tabular}

Source: COBAC. 1/ Estimates based on weights used prior to 2005. 2/ Estimates based on weights used since 2005.

Statistical Appendix. Table 4. Changes in Banks' Ratings, 2001-05

(In number of banks 1/)

\begin{tabular}{|c|c|c|c|c|c|c|c|c|c|c|c|c|}
\hline & \multicolumn{2}{|c|}{ Solid } & \multicolumn{2}{|c|}{ Good } & \multicolumn{2}{|c|}{$\begin{array}{c}\text { Slightly } \\
\text { Fragile }\end{array}$} & \multicolumn{2}{|c|}{$\begin{array}{c}\text { Moderately } \\
\text { Fragile }\end{array}$} & \multicolumn{2}{|c|}{$\begin{array}{c}\text { Very } \\
\text { Fragile }\end{array}$} & \multicolumn{2}{|c|}{ Critical } \\
\hline & 2001 & 2005 & 2001 & 2005 & 2001 & 2005 & 2001 & 2005 & 2001 & 2005 & 2001 & 2005 \\
\hline Cameroon & 0 & 3 & 5 & 4 & 1 & 1 & 1 & 1 & 1 & 0 & 1 & 2 \\
\hline CRA & 0 & 1 & 1 & 1 & 0 & 0 & 2 & 0 & 0 & 0 & 0 & 1 \\
\hline Congo & 0 & 0 & 1 & 3 & 0 & 0 & 0 & 0 & 0 & 0 & 0 & 1 \\
\hline Gabon & 0 & 2 & 5 & 4 & 0 & 0 & 0 & 0 & 0 & 0 & 0 & 0 \\
\hline Equ. Guinea & 1 & 0 & 1 & 2 & 0 & 0 & 0 & 1 & 0 & 0 & 0 & 0 \\
\hline Chad & 0 & 0 & 2 & 2 & 1 & 1 & 2 & 1 & 0 & 2 & 0 & 0 \\
\hline CEMAC & 1 & 6 & 15 & 16 & 2 & 2 & 5 & 3 & 1 & 2 & 1 & 4 \\
\hline
\end{tabular}

Source: COBAC. 1/ Some banks are not rated by COBAC. A fourth bank will start its operations in Equatorial Guinea soon. 